TARNOWSKIE STUDIA TEOLOGICZNE 35 (2016) NR 2, S. 183-184

http://dx.doi.org/10.15633/tst.2116

bp Andrzej Jeż

TARNÓW

\title{
Wręczenie pamiątkowego tomu "Tarnowskich Studiów Teologicznych" dedykowanego ks. prof. dr. hab. Michałowi Hellerowi \\ z okazji 8o. rocznicy urodzin \\ (Tarnów, 10 czerwca 2016 roku)
}

Czcigodny Księże Profesorze, Dostojny Jubilacie!

Szanowni zgromadzeni Goście, duchowni i świeccy!

Świętując swoje 8o. urodziny, ks. prof. Michał Heller powiedział, iż „najmniejszą jego zasługą jest to, że ma osiemdziesiąt lat”. To prawda. Ale z pewnością wielką zasługą Księdza Profesora jest to, w jaki sposób ów czas osiemdziesięciu lat życia spożytkował.

Historia życia Księdza Profesora odsłania tak wiele człowieczego piękna, jakie ujawnia się nie tylko w sprzyjających ku temu warunkach, ale zwłaszcza wtedy, gdy ciężar życiowych doświadczeń tak bardzo przygniata do ziemi, przesłaniając błękit nieba i ludzkiego wnętrza.

Mądrość życiowa, pogodna ducha, poczucie humoru i ciepła osobowość Księdza Profesora są jak silne oddziaływanie grawitacyjne, które przyciąga ku niemu tak wiele osób.

Potężny dorobek naukowy Księdza Profesora - można powiedzieć - iż zakrzywia czasoprzestrzeń pracy innych ludzi nauki, którzy korzystają z jego dorobku, odwołują się do niego i dzięki niemu mogą także iść dalej.

Bóg i nauka - to dwie drogi Księdza Profesora do jednego celu; dwie drogi, które pozwalają uchwycić przemijanie i posmakować najgłębszego sensu.

Pragnę z całego serca wyrazić Księdzu Profesorowi wdzięczność za świadectwo umiłowania mądrości i duchowości, i za tak twórcze spożytkowanie 8o lat swojego życia. Tak wielu z nas tutaj obecnych czuje się przecież jego uczniami. Czujemy się uczniami i dłużnikami!

„Wszystkie słowa sprawiają, że się widzi tylko połowę” - pisał ks. Jan Twardowski. Ks. prof. Michał pokazuje swoim życiem, iż wiedzę należy łączyć 
z mądrością, naukę z wiarą, człowieka i jego świat z Bogiem. Tylko wtedy możliwe jest przekroczenie granicy słów i ogarnięcie całości.

Gorąco życzymy Księdzu Profesorowi siły i młodości, jakie daje głęboka wiara i umiłowanie nauki. Ich horyzonty są zawsze szeroko rozwarte i niejako pomagają uchwycić przemijanie.

Życzymy wielu kolejnych twórczo przeżywanych lat. Dzięki rozwojowi astrofizyki i kosmologii wiemy, że najszlachetniejsze pierwiastki powstają jako ostatnie w cyklu życia gwiazd. Dlatego z radością i oczekiwaniem przyjmujemy każdą nową książkę Księdza Profesora.

Życzymy także Księdzu Profesorowi dobrych i godnych kontynuatorów naukowego warsztatu. To bardzo ważne dla każdego człowieka nauki.

Życzymy wielu powodów do przeżywania radości, satysfakcji i poczucia spełnienia. Naszą wdzięczność, gratulacje i życzenia łączymy z pięknym przesłaniem słów: Szczęść Boże! 